\title{
Ventriküler Septal Defekti Olan Bebeklerde Gama-Glutamil Transferaz Yüksekliği Kalp Yetersizliği ile İlişkili midir?
}

\author{
Fatih Aygün'® ${ }^{1}$, Ahmet İrdem²®
}

'İstanbul Üniversitesi-Cerrahpaşa, Çocuk Sağlığı ve Hastalıkları, Çocuk Yoğun Bakım, İstanbul, Türkiye ${ }^{2}$ SBÜ. Okmeydanı Eğitim ve Araştırma Hastanesi, Çocuk Sağlığı ve Hastalıkları, Çocuk Kardiyolojisi, İstanbul, Türkiye

Fatih Aygün, Dr. Öğr. Üyesi Ahmet İrdem, Doç. Dr.

Illetişim:

Dr. Öğr. Üyesi Fatih Aygün

İstanbul Üniversitesi-Cerrahpaşa, Çocuk Sağlığı

ve Hastalıkları, Çocuk Yoğun Bakım, İstanbul,

Türkiye

Tel: +9021241430 00/ 67272

E-Posta: faygun9@hotmail.com

\section{ÖZET}

Amaç: Doğuştan kalp hastalıkları içinde en sık görüleni olan ventriküler septal defekt (VSD) doğumdan 6-8 hafta sonra pulmoner vasküler direncinde azalmasıyla birlikte kalp yetersizliğine neden olabilir. Kalp yetersizliği klinik bulguları özellikle bebeklerde silik olabilir. Bu nedenle tanısı ve takibinde laboratuvar değerlerinden faydalanılır. Yetişkin hastalarda gama-glutamil transferaz (GGT) ile kalp yetersizliği arasında ilişki gösterilmiştir. Biz de bu çalışma ile VSD nedeniyle kalp yetersizliği gelişen hastalarda karaciğer enzimlerini, özellikle GGT düzeyini değerlendirmeyi amaçladık.

Hastalar ve Yöntem: Bir ay ile bir yaş arasındaki hastaların verileri geriye dönük olarak hasta incelendi. Kalp yetersizliği kliniği ile Ç̧B'a yatııılan ve kesin kalp yetersizliği tanısı konulan VSD'li hastalar değerlendirildi. Karaciğer enzim düzeyleri kalp yetersizliği olan ve olmayan hastalar arasında karşılaştırıldı.

Bulgular: Toplamda 25 hastada VSD ve kalp yetersizliği saptandı. Ortalama hasta yaşı $6,83 \pm 3,71$ aydı. Hastaların 15 'inde $(\% 60,0)$ mekanik ventilatör kullanılırken ortalama yoğun bakım yatış süresi $15,32 \pm 13,85$ gündü. Kalp yetersizliği olan ve olmayan hastalar arasında alanin aminotransferaz (ALT) ( $p<0.001)$, aspartat aminotransferaz (AST) ( $<<0.001)$, gamma-glutamil transferaz $(G G T)(p=0,013)$ ve laktat dehidrogenaz $(\mathrm{LDH})(p=0,026)$ arasında anlamlı ilişki saptandı. ROC eğrisi analizinde eğri altındaki alan (AUC) ALT için 0,849 , AST için 0,792 , LDH için 0,660 ve GGT içinde 0,785 saptandı.

Sonuç: Sonuç olarak VSD'si olan bebeklerde karaciğer enzim yüksekliği kalp yetersizliğinin erken habercisi olabilir.

Anahtar sözcükler: Çocuk yoğun bakım, kalp yetersizliği, karaciğer, ventriküler septal defekt

IS GAMMA-GLUTAMYL TRANSFERASE ELEVATION ASSOCIATED WITH CARDIAC FAILURE IN INFANTS WITH VENTRICULAR SEPTAL DEFECT?

\section{ABSTRACT}

Purpose/Aim: Ventricular septal defect (VSD) which is the most common cause of congenital heart defects in children, can lead to heart failure 6-8 weeks after birth due to the decrease in the pulmonary vascular resistance. The clinical features of cardiac failure can be subtle during the infant period, so the laboratory parameters can help the diagnosis and the follow-up. The relation between gamma-glutamyl transferase (GGT) and cardiac failure is reported in adults. Herein, we aimed to evaluate the relationship between liver enzymes especially GGT levels and cardiac failure developing due to VSD in pediatric patients.

Patients and Methods: The medical records of patients age between 1 month and 1 year old were analysed retrospectively. The patients were admitted in the pediatric intensive care unit (PICU) with clinical manifestations of cardiac failure and patients with VSD having a certain cardiac failure were evaluated. The liver enzyme levels were compared among patients having cardiac failure or not.

Results: Ventricular septal defect and cardiac failure were determined in 25 patients totally. The mean age of the patients was $6.83 \pm 3.71$ months. Fifteen patients $(60.0 \%)$ used to have mechanical ventilation support and the mean duration of hospitalization in the intensive care unit was $15.32 \pm 13.85$ days. As the patients were separated in two groups having cardiac failure and not, there was statistically a relation between alanine aminotransferase (ALT) $(p<0.001)$, aspartate aminotransferase (AST) $(p<0.001)$, gamma-glutamyl transferase (GGT) $(p=0.013)$ and lactate dehydrogenase (LDH) $(p=0.026)$ levels. Analysis of ROC curves was demonstrated as $0.849,0.792,0.660$ and 0.785 respectively for ALT, AST, LDH and GGT.

Conclusion: The increased liver enzyme levels can be an early marker of cardiac failure in infants with VSD.

Keywords: Pediatric intensive care, cardiac failure, liver, ventricular septal defect 
D oğuştan kalp hastalıkları yenidoğan ve süt çocukluğu döneminde emmede azalma, üfürüm, siyanoz, solunum sıkıntısı ve sık enfeksiyon gibi çeşitli bulgularla yapılan ekokardiyografi (EKO) ile tanısı konulan, gecikildiğinde kalp yetersizliği gibi ağır tablolara neden olan hastalıklardır. Doğuştan kalp hastalığı sıklığı tüm canlı doğumlarda yaklaşık $\% 0,5-0,8$ olup, bu oran ölü doğumlarda, düşüklerde ve prematüre bebeklerde artmaktadır (1). Siyanotik ve asiyanotik doğuştan kalp hastalıkları içinde en sık görüleni \%25-30 sıklıkta ventriküler septal defektir (VSD) (2). Ülkemizde yapılan çalışmalarda da VSD sıklığı benzer olarak saptanmıştır $(3,4)$.

VSD sol-sağ şantlı doğuştan kalp hastalığıdır. Bu hastalarda ventriküller arasında geniş açıklık varsa doğumdan itibaren 6-8 hafta sonra yüksek pulmoner vasküler direncin de azalması ile kalp yetersizliği bulguları gelişir (5). Bunun sonucunda da hızla klinik kötüleşme ve sonrasında da çocuk yoğun bakım (ÇYB) ihtiyacı doğabilir. Karaciğer de gelişen konjesyon sonucu karaciğer fonksiyonları bozulur. Özellikle sağ kalp yetmezliğinde hepatik konjesyona bağlı sarılık da eşlik edebilir (6).

Sık görülen bu durumun erken fark edilmesi ve takibi klinik önem arz etmektedir. Bu amaçla geliştirilmiş BNP gibi kalbe özgü biyo-belirteçler vardır (7). Bu belirteçlerin özgüllüğü ve duyarlıığı fazla olmasına rağmen her merkezin ulaşamayacağı pahalı ve çalışııması deneyim isteyen testlerdir. Bu nedenle biz de bu çalışmada daha ucuz, hızlı bakılan ve günlük kullanıma uygun testlerden olan karaciğer fonksiyon testlerinin VSD'ye bağlı kalp yetersizliği olan hastalarda tanı için kullanılabilir olup olmayacağını araştırmayı amaçladık.

\section{Gereç ve yöntem}

Çocuk yoğun bakım Ünitesi'ne Ekim 2016-Mart 2018 tarihleri arasında yatırılan bir ay ile bir yaş altı hastaların verileri geriye dönük olarak hasta dosyaları ve elektronik kayıt sistemleri üzerinden incelendi. Kalp yetersizliği kliniği ile ÇYB'a yatırılan hastalardan elektrokardiografi, radyoloji (telekardiografi) ve EKO ile kesin olarak kalp yetersizliği tanısı konulan VSD'li hastalar toplandı. VSD dışı kalp hastalıkları, kronik ya da akut hepatit, kronik karaciğer hastalığı, karaciğer fonksiyonlarını bozabilecek ilaç kullanan, ilk gün ölen ve bir günden kısa yatışı olan hastalar çalışma dışı bırakıldı.

Çalışmaya alınan tüm hastaların demografik bilgileri ve yatışı sonrası ilk laboratuvar değerlerindeki karaciğer enzimleri kaydedildi. Hastalar VSD'li ve diğer hatlara olacak şekilde iki gruba ayrıldı İlk gün laboratuvar bulguları ile prognostik faktörleri ve mortalitesi VSD'li grup ile diğer hastalar arasında karşılaştıııldı. Gruplar arasındaki cinsiyet, yaş, pediatrik mortalite risk skoru (PRISM-III) ve mortalite ilişkisi değerlendirildi. Ayrıca ilk yatış karaciğer fonksiyon testleri olan alanin aminotransferaz (ALT), aspartat aminotransferaz (AST), gamma-glutamil transferaz (GGT) ve laktat dehidrogenaz (LDH) değerleri kaydedildi (Tablo-1). Çalışmamız için hastanemiz lokal etik kurulundan onay alınmıştır (21.11.2017-763).

İstatistiksel analizde SPSS programı (21,0 sürümü, IBM Company, SPSS Inc.) kullanıldı. Sayısal veriler ortalama \pm standart sapma, kategorik veriler ise sıklık (n) ve yüzde (\%) ile belirtildi. Grup arasındaki farklılıkların istatistiksel anlamlılığının değerlendirilmesinde ANOVA ile analiz edildi. İki nominal değişken arasındaki ilişkinin değerlendirilmesinde Pearson ki kare testi kullanıldı. ROC eğrisi analizi ile karaciğer fonksiyon testlerinin VSD ve kalp yetersizliği ilişkisine bakıldı. İstatistiksel anlamlıık p değerinin 0,05'in altı olarak kabul edildi.

\section{Bulgular}

Toplamda 25 hastada VSD ve kalp yetersizliği saptandı. Hastaların $15^{\prime} \mathrm{i}(\% 60,0)$ erkek, 10 'u $(\% 40,0)$ kız hastaydı. Yaş dağılımları 1 ay ile 1 yaş arasında olup ortalama hasta yaşı $6,83 \pm 3,71$ aydı. Hastaların $15^{\prime}$ inde $(\% 60,0)$ mekanik ventilatör kullanılırken ABH $12(\% 48,0)$ olarak saptandı. PRISMIII skoru $21,25 \pm 10,79$, ortalama yoğun bakım yatış süresi $15,32 \pm 13,85$ gündü. Hastaların biri $(\% 4,0)$ öldü. Başvuru ALT: 113,88 179,60 IU/L, AST: 200,64 $\pm 414,89$ IU/L, GGT: 89,84 $\pm 60,62$, LDH: 574,88 $\pm 396,57$ IU/L saptandı.

Hastalar VSD'ye bağlı kalp yetersizliği olan ve olmayan olarak iki gruba ayrıldığında gruplar arasında cinsiyet, yaş ve mortalite arasında farklılık saptanmadı $(p>0,005)$ Kalp yetersizliği ile mekanik ventilasyon $(p=0,002), A B H$ $(p<0,001)$, PRiSM-III skoru $(p<0,001)$, yoğun bakım yatış süresi $(p<0,001)$, ALT $(p<0,001)$, AST $(p<0,001)$, GGT $(p=0,013)$, $\mathrm{LDH}(p=0,026)$ arasında anlamlı ilişki saptandı (Tablo 1).

Kalp yetersizliği olan grupta karaciğer enzimleri için ROC eğrisi analizinde ALT için eğri altındaki alan (AUC) 0,849 olup kesme noktası 37,50IU için seçicilik \%92,0 ve duyarlılık \%80,3 saptandı. Aynı eğride AST için AUC: 0,792, kesme noktası 46,5IU için seçicilik \%84,9 ve duyarlılık $\% 70,2$, LDH için AUC: 0,660, kesme noktası 369,50IU için seçicilik \%68,0 ve duyarlılık \%62,9, GGT için AUC: 0,785, kesme noktası 52,00IU için seçicilik \%88,0 ve duyarlılık \%69,1 idi (Tablo 2). Karaciğer enzimleri ile VSD-kalp yetersizliği için ROC eğrisi Şekil 1'de gösterilmiştir. 
Tablo 1. Çocuk yoğun bakım hastalarında VSD ile ilişkili prognostik faktörler ve başvurudaki karaciğer fonksiyonlarının karşılaştırıması

\begin{tabular}{lccc} 
Ventriküler septal defekt (VSD) & Evet, $(\boldsymbol{n = 2 5 )}$ & Hayır, $(\boldsymbol{n = 1 7 8})$ & $p$ değeri \\
\hline Cinsiyet & $15(\% 60,0)$ & $104(\% 49,5)$ & 0,881 \\
- Erkek & $10(\% 40,0)$ & $74(\% 50,5)$ & 0,866 \\
- Kız & $6,83 \pm 3,71$ & $6,68 \pm 4,20$ & 0,002 \\
Yaş (ay) & $15(\% 60,0)$ & $52(\% 23,4)$ & $<0,001$ \\
Mekanik ventilasyon & $12(\% 48,0)$ & $31(\% 21,8)$ & $<0,001$ \\
Akut böbrek hasarı & $21,25 \pm 10,79$ & $11,95 \pm 9,45$ & 0,872 \\
PRisM-III skoru & $1(\% 4,0)$ & $6(\% 12,8)$ & $<0,001$ \\
Mortalite & $15,32 \pm 13,85$ & $7,78 \pm 7,54$ & $<0,001$ \\
Yoğun bakım yatıs süresi & $113,88 \pm 179,60$ & $30,51 \pm 43,74$ & $<0,001$ \\
Alanin aminotransferaz (ALT) (IU/L) & $200,64 \pm 414,89$ & $55,71 \pm 102,17$ & 0,013 \\
Aspartat aminotransferaz (AST) (IU/L) & $89,84 \pm 60,62$ & 0,026
\end{tabular}

Table 2. Başvuru karaciğer fonksiyonlarının ROC analizi ile kalp yetersizliği arasındaki ilişkisi

$95 \%$ C. I.

\begin{tabular}{lcccccccc}
\hline Parametre & AUC & S. . & $p$ value & Alt sınır & Üst sınır & Kesme noktası & Duyarlılık & Özgüllük \\
\hline ALT (IU/L) & 0,849 & 0,037 & $<0,001$ & 0,777 & 0,922 & 37,50 & $\% 92,0$ & $\% 80,3$ \\
AST (IU/L) & 0,792 & 0,039 & $<0,001$ & 0,719 & 0,866 & 46,50 & $\% 84,90$ & $\% 70,2$ \\
LDH (IU/L) & 0,660 & 0,058 & 0,010 & 0,546 & 0,773 & 369,50 & $\% 68,0$ & $\% 62,9$ \\
GGT (IU/L) & 0,785 & 0,032 & $<0,001$ & 0,723 & 0,847 & 52,00 & $\% 88,0$ & $\% 69,1$ \\
\hline
\end{tabular}

S. E., standart sapma; C. I., confidence interval, ALT, alanin aminotransferaz; AST, aspartat aminotransferaz; LDH, laktat dehidrogenaz; GGT, gama-glutamil transferaz.

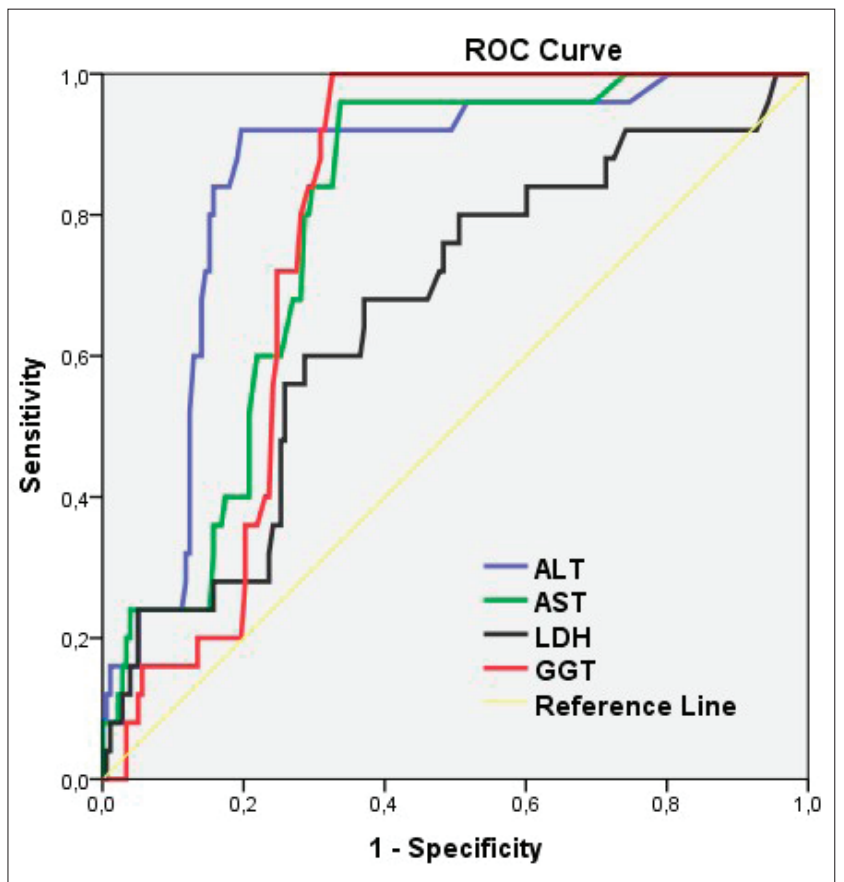

Şekil 1. Çocuk yoğun bakımda kalp yetersizliği hastalarının karaciğer fonksiyonlarının ROC eğrileri ile karşılaştıııması (ALT, alanin aminotransferaz; AST, aspartat aminotransferaz; GGT, gama-glutamil transferaz; LDH, laktat dehidrogenaz).

\section{Tartışma}

Bu retrospektif çalışmada bir yaş altı bebeklerde karaciğer fonksiyon testleri ile VSD'ye bağlı kalp yetersizliği arasında anlamlı ilişki saptandı. Özellikle karaciğer için daha spesifik olan ALT kalp yetersizliği ile daha yakın ilişkiliydi. Daha sonra GGT yüksekliği geliyordu. Bu ilişki daha önce yetişkin hasta çalışmalarında gösterilmesine rağmen çocuk hastalarda az sayıda bilgi mevcuttur.

Kalp yetersizliği, kalbin dokuların gereksinimi olan kanı organlara ve perifere gönderememesi sonucunda gelişen klinik bir durumdur. Yetersiz sistemik kanlanma sonucu devreye giren kompansatuvar mekanizmalara ve venöz göllenmeye bağlı olarak hastalarda yaş grubuna göre değişen klinik bulgular ortaya çıkar $(8,9)$. Süt çocukluğu döneminde doğuştan kalp hastalıkları kalp yetersizliğinin en sık nedenidir $(9,10)$. Bebeklerde kalp yetersizliği kliniği büyük çocuk ve yetişkinden farklılık gösterir. Tanı almaları da bu nedenle zor olabilir. Kalp yetersizliği düşündüren klinik özellikler arasında taşipne, taşikardi, beslenme zorluğu, ses kısıklığı, terleme ve büyüme geriliği yer alır (10). Bizim çalışmamızda VSD'ye bağlı kalp yetersizliği 25 
$(\% 12,3)$ hastada vardı. Bu hastaların ortak ve en sık bulgu ise sinüs taşikardisiydi. Diğer bir ilginç özelliği hastaların başvuru yaşıydı. Yaş ortalaması aslında VSD'ye bağlı kalp yetersizliği için geç başvuru yaşıydı. Mevcut hastaların 22 (\%88)'inde başvuru öncesi enfeksiyon geçirme öyküsü vardı. Muhtemel hastaların ani bozulmasında araya giren enfeksiyonlar neden olmuştu.

GGT glutatyon metabolizmasında görev alan önemli bir enzim olup karaciğer ve safra yolları hastalıklarının bir indikatörü olarak bilinmektedir. Özellikle GGT proksimal renal tübül, pankreas ve barsak başta olmak üzere karaciğerde aktif olarak bulunur (11). Serum düzeyindeki yüksekliğin diyabet, hipertansiyon ve metabolik sendromla ilişkisi daha önce gösterilmiştir (12). Fakat son yıllarda GGT ile ilgili yetişkin hastalarda yapılan çalışmalarda kardiyovasküler hastalıklar ile de ilişkili olduğu bildirilmiştir. Bu ilişkide özellikle lipoproteinlerin metabolizmasındaki değişiklik suçlanmaktadır. Ayrıca, serum GGT düzeyinin, risk faktörü olmayan hipertansif hastalarda hedef organ hasarının bağımsız bir göstergesi olarak yükselebileceği bildirilmiştir (13). Yine yetişkin hastalarda yapılan ve 1087 kalp yetersizliğinin dahil edildiği çalışmada GGT yüksekliğinin erkek hastalarda \%43, kadın hastalarda ise $\% 48$ olduğu ve GGT yüksekliğinin kötü prognoz ile ilişkili bağımsız bir risk faktörü olduğu gösterilmiştir (11). Yetişkin çalışmalarında GGT'nin kalp yetersizliğinde hastaların takibi için de kullanılabileceği de bildirildikten sonra çalışmalar kalp yetersizliğinde GGT'ye odaklanmıştır (14). Bu örneklerden de anlaşılacağı üzere serum GGT düzeyinin yetişkin hastalarda prognostik bir faktör olarak gösterilmesine rağmen çocuklarda konuyla ilgili çalışma bulunmamaktadır. Bunun nedeni çocuklarda yetişkinlerden farklı olarak GGT'nin yaş

\section{Kaynaklar}

1. Bernstein D. Congenital heart disease. In: Behrman RE, Kliegman RM, Jenson HB, editors. Nelson Textbook of Pediatrics, 17th ed. Philadelphia: Saunders; 2004. p.1499-554.

2. Hoffman JIE, Kaplan S, Liberthson RR. Prevalence of congenital heart disease. Am Heart J 2004;147:425-39. [CrossRef]

3. Zan S, Yapıcıoğlu H, Erdem S, Özlü F, Satar M, Özbarlas N ve ark. Çukurova Üniversitesi Tıp Fakültesi Hastanesi yenidoğan yoğun bakım ünitelerinde son beş yılda izlenen konjenital kalp hastalarının retrospektif incelenmesi. Çocuk Sağlığı ve Hastalıkları Derg 2015;58:7-16.http://www.cshd.org.tr/uploads/pdf_CSH_554.pdf

4. Ekici F, Ünal S, Dablan S, Alpan N, Çevik B, Vidinlisan S. Yenidoğan yoğun bakım ünitesindeki 119 bebeğin klinik ve ekokardiyografik değerlendirilmesi. Türkiye Çocuk Hastalıkları Derg 2010;4:22-9. https://dergipark.org.tr/tr/download/article-file/689238

5. Azak E, Ünsal H, Kibar AE, Çetin ii. Çocuklarda Konjestif Kalp Yetersizliği. Türkiye Çocuk Hastalıkları Dergisi 2016;3:223-32. [CrossRef] faktöründen etkilenmesi olabilir (15). Biz de çalışmamızda bu bilgi doğrultusunda GGT referans aralığının değişmediği 1 ay ile 1 yaş hasta grubunu inceledik. Ayrıca VSD dışı ek kronik hastalığı olan hastaları da çalışma dışı bıraktık. Çalışmamızda yetişkin çalışmalara benzer olarak GGT ile kalp yetersizliği arasında anlamlı ilişki bulduk. Serum GGT ile kalp yetersizliği için ROC eğrisi analizi yapıldığında anlamlı ilişki Şekil 1'de de görüldüğü gibi anlamlı saptandı.

Yüksek santral venöz basıncın kalp yetersizliği hastalarında serum GGT seviyeleri ile ilişkili olduğu ve bunun sonucunda bozulan karaciğer fonksiyonlarının serum GGT düzeylerini arttırdığı bildirilmiștir (16). Bizim çalıșmamızdaki hastalarda da karaciğer fonksiyon testlerindeki bozulma bu mekanizma ile açıklanabilir. Serum ALT, AST ve LDH düzeyini diğer yoğun bakım hastalarından anlamlı olarak yüksek saptadık. Şekil 1'de de görüldüğü gibi ROC eğrisi analizinde en anlamlı ilişki ALT (AUC: 0,849) ile saptandı.

Çalışmamızda bazı eksiklikler ve kısıtlamalar bulunmaktadır. Retrospektif ve tek merkezli olması, karaciğer fonksiyon testlerinin sadece yatış değerlerinin çalışmaya alınması, seri ölçüm ile takip edilmemesi ve bilirubin düzeylerinin ölçülmemesi eksik yönleridir. Konuyla ilgili çocuk hastalarda daha önce yapılmış çalışma olmaması çalışmamızı değerli kılmaktadır.

Sonuç olarak VSD'si olan bebeklerde karaciğer enzim yüksekliği kalp yetersizliğinin erken habercisi olabilir. Çocuklarda kalp yetersizliği ve GGT ile ilişkiyi değerlendirmek için yetişkin çalışmalar gibi geniş hasta topluluklarının dahil edildiği çok merkezli prospektif çalışmalara ihtiyaç olduğunu düşünmekteyiz.

6. Masarone D, Valente F, Rubino M, Vastarella R, Gravino R, Rea $A$, et al. Pediatric Heart Failure: A Practical Guide to Diagnosis and Management. Pediatr Neonatol 2017;58:303-12. [CrossRef]

7. Ko KH, Lee JH, Choi BM, Lee JH, Yoo KH, Son CS, Lee JW. Utility of the rapid B-type natriuretic peptide assay for detection of cardiovascular problems in newborn infants with respiratory difficulties. Neonatalogy 2008;94:16-21. [CrossRef]

8. Auslender M. Pathophysiology of pediatric heart failure. Progress Pediatr Cardiol 2000;11:175-84. [CrossRef]

9. O'Laughlin MP. Congestive heart failure in children. Pediatr Clin North Am 1999;46:263-73. [CrossRef]

10. Jayaprasad N. Heart Failure in Children. Heart Views 2016;17:92-9. [CrossRef]

11. Ess M, Mussner-Seeber C, Mariacher S, Lorsbach-Koehler A, Pachinger $\mathrm{O}$, Frick $\mathrm{M}$, et al. Gammaglutamyltransferase rather than total bilirubin predicts outcome in chronic heart failure. J Card Fail 2011;17:577-84. [CrossRef] 
12. Onat A, Can G, Ornek E, Çiçek G, Ayhan E, Doğan Y. Serum gammaglutamyltransferase: Independent predictor of risk of diabetes, hypertension, metabolic syndrome, and coronary disease. Obesity 2012;20:842-8. [CrossRef]

13. Sen N, Ozlu MF, Basar N, Ozcan F, Güngör O, Turak O, et al. Relationship between elevated serum gammaglutamyltransferase activity and slow coronary flow. Arch Turk Soc Cardiol 2009;37:168-73. https://www.journalagent.com/tkd/ pdfs/TKDA_37_3_168_173.pdf
14. Poelzl G, Eberl C, Achrainer H, Doerler J, Pachinger O, Frick M, Ulmer $\mathrm{H}$. Prevalence and prognostic significance of elevated gamma-glutamyltransferase in chronic heart failure. Circ Heart Fail 2009;2:294-302. [CrossRef]

15. Cabrera-Abreu JC, Green A. Gamma-glutamyl trasferase: value of its measurement in pediatrics. Ann Clin Biochem 2002;39:22-5. [CrossRef]

16. van Deursen VM, Damman $K$, Hillege $H L$, van Beek AP, van Veldhuisen DJ, Voors AA. Abnormal liver function in relation to hemodynamic profile in heart failure patients. J Card Fail 2010;16:84-90. [CrossRef] 